\title{
Factors Affecting Scholastic Performance in School Children.
}

\author{
Pagadpally Srinivas ${ }^{1}$, S.Venkatkrishnan ${ }^{2}$ \\ ${ }^{1}$ Associate Professor, Dept of Paediatrics, Vinayaka Mission's Medical College, Karaikal \\ ${ }^{2}$ Registrar, Ramakrishna Hospital, Coimbatore.
}

\begin{abstract}
:
Aim: To assess-

i)Factors that influence the school performance of children;

ii)To determine modifiable the factors;

iii)To offer counseling for parents, teachers and students whenever needed

Methodology: This study is a prospective, school based, horizontal study among 1000 secondary school

children in age group 10 to 15 years in Karaikal region.

Results:

$\checkmark$ Well educated parents shows positive influence on academic achievements of children.

$\checkmark$ Teachers play a vital role in the academic performance of children. Good attendance commiserates with good scholastic performance

$\checkmark \quad$ Family disharmony showed negative influence on scholastic performance.

Keywords: scholastic performance; broken home; teacher influence.
\end{abstract}

\section{Introduction}

Scholastic achievement has become an index of child's future in this highly competitive world Poor scholastic performance has a significant impact on the child and adolescent potential in the society.

Factors Influencing School Performance:

i) Home related factors:-

Factors which hinders school performance are Parental illiteracy, lack of encouragement and lack of role models, Alcoholic and workaholic parents, contribute to academic performance. ${ }^{2,3}$

ii)The school related factors:-

The child spends most of his time in school and here his environment is exerting a different influence on performance through curricula, teaching techniques, relationship ${ }^{4,5}$

iii)Child-Teacher Relationships:-

A growing body of evidence supports this claim as child-teacher attachment relationships have been found to be important for children's social and emotional development. ${ }^{6}$

\section{The psychological factors:}

Psychosocial factors (PSFs) such as motivation, social control, and self regulation, play key roles in classroom learning. ${ }^{7}$ The motivation to achieve academic outcomes in educational settings via certain personality characteristics and attitudes will bring the desired outcome in scholastic performance. ${ }^{8}$

\section{Disease related factors:}

These conditions have been reported to have an independent effect resulting in scholastic performance.

i)Visual impairment: worsening in handwriting and slowness in copying from the board.

ii)Hearing Impairment:

Even mild to moderate hearing loss in childhood is associated with poor language development and lower educational.

To assess

\section{Aims And Objectives}

I. Factors that influence the school performance of children

1. Home related factors

2. School related factors

3. Social related factors

4. Psychological related factors

5. Disease related factors. 
II. To determine modifiable the factors.

III. To offer counseling for parents, teachers and students whenever warranted.

\section{Ethical Issues}

The clearance was obtained from ethical committee of Vinayaka Missions Medical College \& Hospitals prior to the study. The permission to conduct this study was obtained from The Chief Educational Officer of Karaikal. Necessary permission from the Principals of the schools was obtained.

\section{Materials And Methods}

Study design: This study is a prospective, school based, horizontal study among secondary school children in Karaikal region.

Study subjects: Children of age group between 10 to 15 years studying in $6^{\text {th }}$ to $10^{\text {th }}$ standard in selected 10 schools of Karaikal region.

Study Population: 1000 school children in age group 10 to 15 years from the selected schools of Karaikal. Period of study: The present study was carried out from June 2014 to March 2015,

\section{Methods And Systems For The Study}

The study design for collecting the data was chosen by direct observation of children in the respective schools, interviewing the teachers and children and collecting the data in the form of a questionnaire. The teenage screening questionnaire is obtained from the Child Development Centre (CDC), Thiruvananthapuram, Kerala.

\section{Inclusion criteria:}

1. 10 to 15 years children of 10 selected schools

2. The students who gave oral consent.

\section{Exclusion criteria:}

1. The students with:

I. Chronic medical illness

II. Below average IQ

III. Physically challenged

2. Students who did not give consent

Methodology: After informed verbal consent, the questionnaire was given to students.

In each class the questionnaire and the correct method of filling it up was explained to the students.

Since the participating schools are English medium schools, the original questionnaire of CDC is directly used. The students were counseled to write the answers without any prejudice and bias.

The data was analysed with student's $t$ test, chi square test and relevant statistical tools.

\section{Grading system used:}

\section{Results}

The overall performance of the students was graded as with reference to the marks obtained in the tests/exams held in that academic year, for convenience of data analysis.

1. $>80 \%$ - Excellent $(\mathrm{N}=261)$

2. $60-79 \%-$ Good $(\mathrm{N}=273)$

3. $50-59 \%$ - Average $(\mathrm{N}=219)$

4. $35-49 \%$ - Poor $(\mathrm{N}=185)$

5. $<35 \%$ - Very Poor $(\mathrm{N}=62)$

Figure 1:

\section{Grade \%}

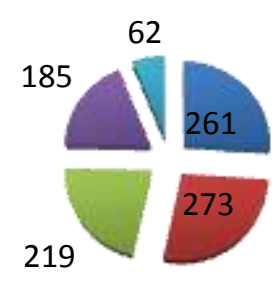


Table 1: AGE

\begin{tabular}{|l|r|r|}
\hline Age & Frequency & \multicolumn{1}{|c|}{ Percent } \\
\hline $10-13 \mathrm{yrs}$ & 760 & 76 \\
\hline $14-17 \mathrm{yrs}$ & 240 & 24 \\
\hline Total & 1000 & 100 \\
\hline
\end{tabular}

Figure 2: SEX

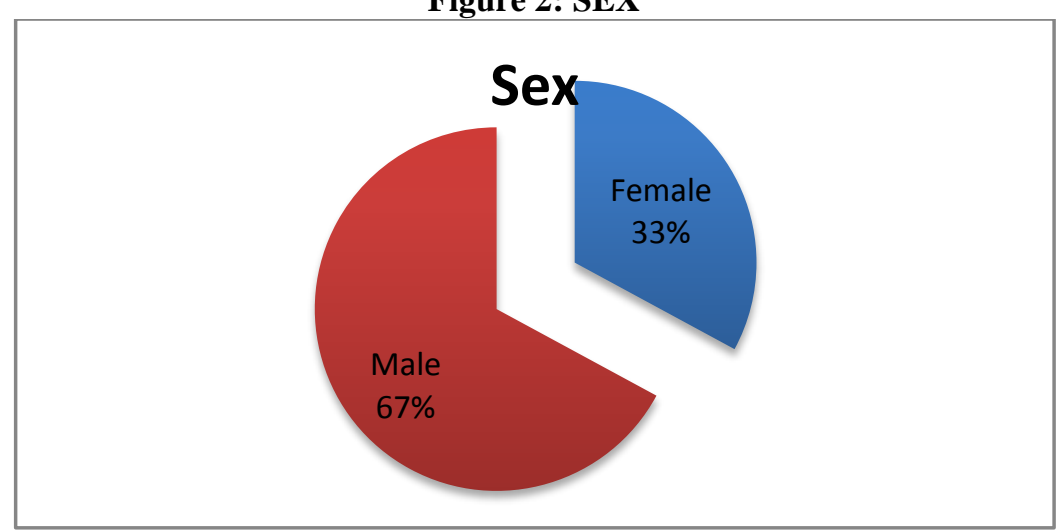

Table 2: SEX VS SCHOLASTIC PERFORMANCE

\begin{tabular}{|c|c|c|c|c|c|c|c|c|}
\hline \multirow[b]{2}{*}{ Sex } & \multicolumn{5}{|c|}{ Grade Percentage } & \multirow[b]{2}{*}{ Total } & \multirow{2}{*}{$\begin{array}{l}\text { Chi- } \\
\text { Square }\end{array}$} & \multirow[b]{2}{*}{$\mathrm{p}$-value } \\
\hline & $\begin{array}{c}\text { Less than } \\
35 \%\end{array}$ & $35-49 \%$ & $50-59 \%$ & $60-79 \%$ & $\begin{array}{c}80 \% \text { and } \\
\text { above }\end{array}$ & & & \\
\hline Female & $18(5.5)$ & $36(10.9)$ & $50(15.2)$ & $86(26.1)$ & $139(42.2)$ & $\begin{array}{l}329 \\
(32.9)\end{array}$ & \multirow{3}{*}{74.851} & \multirow{3}{*}{$<0.001$} \\
\hline Male & $44(6.6)$ & $149(22.2)$ & $169(25.2)$ & $187(27.9)$ & $122(18.2)$ & $\begin{array}{l}671 \\
(67.1)\end{array}$ & & \\
\hline Total & $62(6.2)$ & $185(18.5)$ & 219 (21.9) & $273(27.3)$ & $261(26.1)$ & $\begin{array}{l}1000 \\
(100)\end{array}$ & & \\
\hline
\end{tabular}

Chi Square value $=74.851$

p-value $<0.001$

Conclusion: p value < level of significance $(0.05)$

There is a significant association between Gender and scholastic performance of children.

Female children are having better scholastic performance than male children

Table 3: LITERACY STATUS OF MOTHER VS SCHOLASTIC PERFORMANCE

\begin{tabular}{|c|c|c|c|c|c|c|c|c|}
\hline \multirow[t]{2}{*}{ Literacy status of Mother } & \multicolumn{5}{|c|}{ Grade Percentage } & \multirow[t]{2}{*}{ Total } & \multirow[t]{2}{*}{ Chi-Square } & \multirow[t]{2}{*}{ p-value } \\
\hline & $\begin{array}{l}\text { Less } \\
\text { than } \\
35 \%\end{array}$ & $35-49 \%$ & $50-59 \%$ & $60-79 \%$ & $\begin{array}{c}80 \% \text { and } \\
\text { above }\end{array}$ & & & \\
\hline No Schooling & $0(0)$ & $6(18.8)$ & $5(15.6)$ & $15(46.9)$ & $6(18.8)$ & $32(3.2)$ & \multirow[t]{9}{*}{244.700} & \multirow[t]{9}{*}{$<0.001$} \\
\hline Primary schooling & 16 (11.6) & $33(23.9)$ & $42(30.4)$ & $36(26.1)$ & $11(8)$ & $138(13.8)$ & & \\
\hline Secondary schooling & $26(6)$ & $125(28.7)$ & $104(23.9)$ & $109(25.1)$ & $71(16.3)$ & $435(43.5)$ & & \\
\hline Higher secondary & $7(5.5)$ & $11(8.7)$ & $33(26)$ & $49(38.6)$ & $27(21.3)$ & $127(12.7)$ & & \\
\hline Degree & $8(4.3)$ & $10(5.4)$ & $27(14.6)$ & $52(28.1)$ & $88(47.6)$ & $185(18.5)$ & & \\
\hline Post Graduation & $2(6.5)$ & $0(0)$ & $2(6.5)$ & $5(16.1)$ & $22(71)$ & $31(3.1)$ & & \\
\hline Technical & $2(22.2)$ & $0(0)$ & $0(0)$ & $2(22.2)$ & $5(55.6)$ & $9(0.9)$ & & \\
\hline Professional & $1(2.3)$ & $0(0)$ & $6(14)$ & $5(11.6)$ & $31(72.1)$ & $43(4.3)$ & & \\
\hline Total & $62(6.2)$ & $185(18.5)$ & $219(21.9)$ & $273(27.3)$ & $261(26.1)$ & $1000(100)$ & & \\
\hline
\end{tabular}

Chi Square value $=244.700 \quad \mathrm{p}$-value $<0.001$

Conclusion: $p$ value $<$ level of significance $(0.05)$

Scholastic performance of the students improves as the literacy status of Mother is higher. Scholastic performance of the students becomes poor as the literacy status of the mother is low

Table 4: FACILITATING FACTOR AT HOME VS SCHOLASTIC PERFORMANCE

\begin{tabular}{|c|c|c|c|c|c|c|c|c|}
\hline Facilitating Factor & \multicolumn{5}{|c|}{ Grade Percentage } & Total & $\begin{array}{c}\text { Chi- } \\
\text { Square }\end{array}$ & p-value \\
\cline { 2 - 7 } & $\begin{array}{c}\text { Less } \\
\text { than } \\
35 \%\end{array}$ & $35-49 \%$ & $50-59 \%$ & $60-79 \%$ & $\begin{array}{c}80 \% \text { and } \\
\text { above }\end{array}$ & & \\
\hline
\end{tabular}


Factors Affecting Scholastic Performance In School Children.

\begin{tabular}{|l|l|l|l|l|l|l|l|l|}
\hline No & $19(6)$ & $\begin{array}{l}67 \\
(21.1)\end{array}$ & $83(26.2)$ & $84(26.5)$ & $64(20.2)$ & $\begin{array}{l}317 \\
(31.7)\end{array}$ & 11.984 & 0.017 \\
\hline Yes & $43(6.3)$ & $\begin{array}{l}118 \\
(17.3)\end{array}$ & $\begin{array}{l}136 \\
(19.9)\end{array}$ & $\begin{array}{l}189 \\
(27.7)\end{array}$ & $\begin{array}{l}197 \\
(28.8)\end{array}$ & $\begin{array}{l}683 \\
(68.3)\end{array}$ & \\
& & $\begin{array}{l}219 \\
\text { Total }\end{array}$ & $62(6.2)$ & $\begin{array}{l}273 \\
(18.5)\end{array}$ & $\begin{array}{l}261 \\
(26.9)\end{array}$ & $\begin{array}{l}1000 \\
(100)\end{array}$ & \\
& & $(27.3)$ & $(26.1)$ & \\
\hline
\end{tabular}

Chi Square value $=11.984$

p-value $<0.017$

Conclusion: p value $<$ level of significance $(0.05)$

Facilitating factors at home such as - separate room, separate table, electric light etc.

$46.6 \%$ of children's performance is good to excellent, even if there is no facilitating factor at home

$56.5 \%$ children performance is good to excellent when there is facilitating factor at home

Scholastic performance of the children improves with facilitating factors at home.

Figure 3: ASSISTANCE OF MOTHER FOR STUDY AND SCHOLASTIC PERFORMANCE

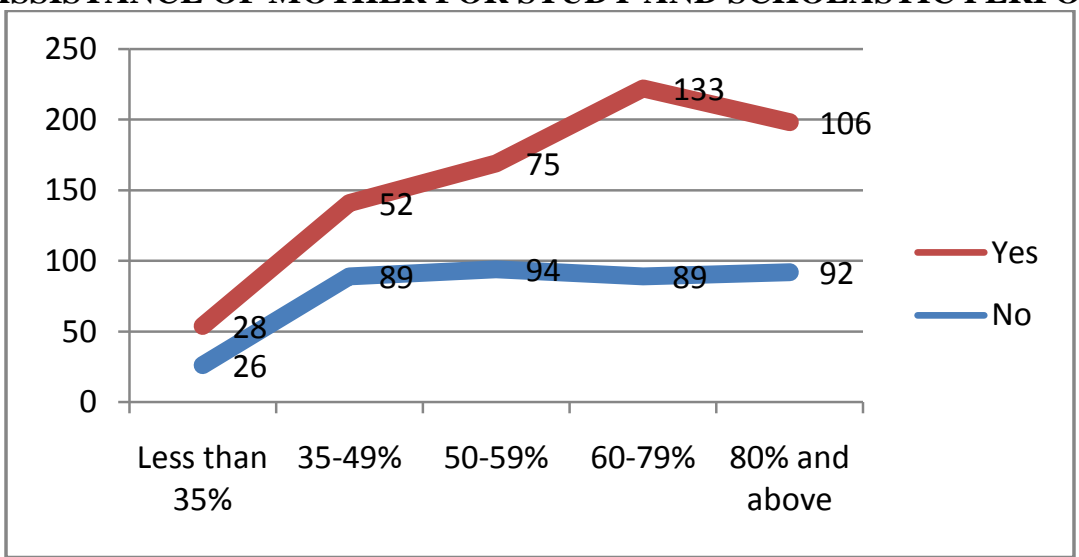

Table 5: INFLUENCE OF TEACHER VS SCHOLASTIC PERFORMANCE

\begin{tabular}{|c|c|c|c|c|c|c|c|c|}
\hline \multirow[b]{2}{*}{$\begin{array}{l}\text { Influence of } \\
\text { teacher(encoura } \\
\text { ging) }\end{array}$} & \multicolumn{5}{|c|}{ Grade Percentage } & \multirow[b]{2}{*}{ Total } & \multirow[b]{2}{*}{$\begin{array}{l}\text { Chi- } \\
\text { Squar } \\
\mathrm{e}\end{array}$} & \multirow[b]{2}{*}{$\begin{array}{l}\text { p- } \\
\text { val } \\
\text { ue }\end{array}$} \\
\hline & $\begin{array}{l}\text { Less } \\
\text { than } \\
35 \%\end{array}$ & $35-49 \%$ & $50-59 \%$ & $60-79 \%$ & $\begin{array}{c}80 \% \\
\text { and } \\
\text { above }\end{array}$ & & & \\
\hline No & $\begin{array}{l}22(47 . \\
8)\end{array}$ & $0(0)$ & $\begin{array}{l}12 \\
(26.1)\end{array}$ & $9(19.6)$ & $3(6.5)$ & $\begin{array}{l}46 \\
(4.6)\end{array}$ & \multirow{3}{*}{$\begin{array}{c}19.09 \\
1\end{array}$} & \multirow{3}{*}{$\begin{array}{l}0.0 \\
01\end{array}$} \\
\hline Yes & $\begin{array}{l}59 \\
(6.1)\end{array}$ & $\begin{array}{l}185 \\
(19.3)\end{array}$ & $\begin{array}{l}207 \\
(21.7)\end{array}$ & $\begin{array}{l}264 \\
(27.7)\end{array}$ & $\begin{array}{l}239 \\
(25.1)\end{array}$ & $\begin{array}{l}954 \\
(95.4) \\
\end{array}$ & & \\
\hline Total & $\begin{array}{l}81(8.1 \\
)^{8}\end{array}$ & $\begin{array}{l}185 \\
(18.5)\end{array}$ & $\begin{array}{l}219 \\
(21.9)\end{array}$ & $\begin{array}{l}273 \\
(27.3)\end{array}$ & $\begin{array}{l}242(24 . \\
2)\end{array}$ & $\begin{array}{l}1000 \\
(100)\end{array}$ & & \\
\hline
\end{tabular}

Chi Square value $=19.091$

p-value $<0.001$

Conclusion: $p$ value $<$ level of significance $(0.05)$

Influence of teacher has shown a positive correlation with scholastic performance of children

Table 6: PROBLEMS IN SCHOOL VS SCHOLASTIC PERFORMANCE

\begin{tabular}{|c|c|c|c|c|c|c|c|c|}
\hline \multirow[b]{3}{*}{ Problems in school } & \multirow{2}{*}{\multicolumn{5}{|c|}{ Grade Percentage }} & \multirow[b]{3}{*}{ Total } & \multirow[b]{3}{*}{ Chi-Square } & \multirow[b]{3}{*}{$\mathrm{p}$-value } \\
\hline & & & & & & & & \\
\hline & $\begin{array}{l}\text { Less } \\
\text { than } \\
35 \%\end{array}$ & $35-49 \%$ & $50-59 \%$ & $60-79 \%$ & $\begin{array}{l}80 \% \text { and } \\
\text { above }\end{array}$ & & & \\
\hline No & $52(83.9)$ & $162(87.6)$ & $183(83.6)$ & $242(88.6)$ & $205(78.5)$ & $844(84.4)$ & \multirow{3}{*}{12.073} & \multirow{3}{*}{0.017} \\
\hline Yes & $10(16.1)$ & $23(12.4)$ & $36(16.4)$ & $31(11.4)$ & $56(21.5)$ & $156(15.6)$ & & \\
\hline Total & $62(6.2)$ & $185(18.5)$ & $219(21.9)$ & $273(27.3)$ & $261(26.1)$ & $1000(100)$ & & \\
\hline
\end{tabular}

Chi Square value $=12.073$

p-value $<0.017$

Conclusion: p value < level of significance $(0.05)$

Problems in school such as harassment, isolation. When there is problems in school, the scholastic performance of the students decreases. 
Factors Affecting Scholastic Performance In School Children.

Table 7: PARENTAL DISHARMONY VS SCHOLASTIC PERFORMANCE

\begin{tabular}{|c|c|c|c|c|c|c|c|c|}
\hline \multirow[b]{2}{*}{$\begin{array}{c}\text { Parental } \\
\text { disharmony }\end{array}$} & \multicolumn{5}{|c|}{ Grade Percentage } & \multirow[b]{2}{*}{ Total } & \multirow[b]{2}{*}{$\begin{array}{l}\text { Chi- } \\
\text { Square }\end{array}$} & \multirow[b]{2}{*}{$\begin{array}{c}\mathrm{p}- \\
\text { value }\end{array}$} \\
\hline & $\begin{array}{l}\text { Less } \\
\text { than } \\
35 \%\end{array}$ & $35-49 \%$ & $50-59 \%$ & $60-79 \%$ & $\begin{array}{c}80 \% \\
\text { and } \\
\text { above }\end{array}$ & & & \\
\hline No & $6(75)$ & $12(35.3)$ & $25(56.8)$ & $32(66.7)$ & $\begin{array}{l}44 \\
(77.2) \\
\end{array}$ & $\begin{array}{l}119 \\
(62.3)\end{array}$ & \multirow{3}{*}{17.443} & \multirow{3}{*}{0.002} \\
\hline Yes & $2(25)$ & $22(64.7)$ & $19(43.2)$ & $16(33.3)$ & $\begin{array}{l}13 \\
(22.8)\end{array}$ & $72(37.7)$ & & \\
\hline Total & $8(5.4)$ & 28 (18.9) & $44(29.7)$ & 29 (19.6) & $\begin{array}{l}39 \\
(26.4)\end{array}$ & $\begin{array}{l}148 \\
(100)\end{array}$ & & \\
\hline
\end{tabular}

Chi Square value $=17.443$

p-value $<0.002$

Conclusion: $p$ value $<$ level of significance $(0.05)$

Parental disharmony and broken family has shown a negative correlation with scholastic performance of children.

Table 8: ALCOHOLISM OF FATHER VS SCHOLASTIC PERFORMANCE

\begin{tabular}{|l|l|l|l|l|l|l|l|l|}
\multirow{2}{*}{$\begin{array}{c}\text { Alcoholism } \\
\text { of father }\end{array}$} & $\begin{array}{c}\text { Less than } \\
35 \%\end{array}$ & $35-49 \%$ & $50-59 \%$ & $60-79 \%$ & $\begin{array}{c}80 \% \text { and } \\
\text { above }\end{array}$ & \multirow{2}{*}{ Total } & Chi-Square & p-value \\
\cline { 2 - 6 } & $1(12.5)$ & $6(17.6)$ & $11(25)$ & $36(75)$ & $48(84.2)$ & $102(53.4)$ & & \\
\hline No & $7(87.5)$ & $28(82.4)$ & $33(75)$ & $12(25)$ & $9(15.8)$ & $89(46.6)$ & 67.849 & $<0.001$ \\
\hline Yes & $8(5.4)$ & $28(18.9)$ & $44(29.7)$ & $29(19.6)$ & $39(26.4)$ & $148(100)$ & & \\
\hline
\end{tabular}

Chi Square value $=67.849 \quad \mathrm{p}$-value $<0.001$

Conclusion: p value $<$ level of significance $(0.05)$

There is a significant association between alcoholism of father and scholastic performance of children. It shows a negative influence in scholastic performance.

\section{DISCUSSION}

The focus of the present study is to analyse how different factors such as home related, school related, psychological, disease related, influence the scholastic performance of children. Hence this study was done across ten schools situated in Karaikal town with a sample size of 1000 students.

\section{Gender}

This study revealed that female children have better scholastic performance than male children. Among the female children, $68.3 \%$ of them have scores good to excellent (>60\% Grade). The present result is comparable to the study done by Saraswati Shashidhar et al ${ }^{9}$ andJ. N. George et al ${ }^{10}$

\section{Facilitating factors at home}

As determined in this study that children performance was better when there is facilitating factor such as ,separate room, separate table, electric light at home, as evidenced by $56.5 \%$ children performing in the good to excellent range as compared to $46.5 \%$ without facilitating factor at home. This is similar to the study done by Meena Siwach nee Daulta et al ${ }^{11}$, Shenoy et al ${ }^{12}$

\section{Parents help for study}

$60.1 \%$ of children who had mothers help, scored good to excellent grade as determined by this study. This shows mothers help had positive influence in scholastic performance of children. Mothers support in her childs education helps in the scholastic performance, which correlates with the study done by Ms Bushra Iqbal Chohan et al ${ }^{13}$

\section{Teachers influence}

The present study brought out, teachers influence shows positive impact on children scholastic performance. 52.7\% of children scored good to excellent grade says teachers are encouraging when compared only $25.1 \%$ of children scored good to excellent grade, who said teachers are not encouraging. This is supported by a study done by M K C Nair et al ${ }^{14}$, S. Paul Wright et al ${ }^{15}$ 


\section{Broken Home}

Scholastic performance of children decreased with Parental disharmony, as determined by this study. This shows that family disharmony has adverse effect on scholastic performance of children. $60 \%$ of children with parental disharmony have very poor to average grade. In our study, broken family has major negative impact on scholastic performance of children. None of the children got good to excellent grade when they were from broken family. Broken family, $63 \%$ of children have poor to very poor scholastic performance. This study is supported by M K C Nair et al ${ }^{17}$, Thomas Babalis et al ${ }^{16}$

\section{Influence of Alcoholism}

This study shows, when alcohol dependence is present in the family, $76.5 \%$ children scholastic performance is very poor to average. This shows alcohol abuse got negative influence on children's scholastic performance which is similar to a study done by Mc Grath CE et al ${ }^{17}$

\section{Visual and ENT problem}

Eye problems such as refactory error, squint, stye and ENT problems such as discharge, sinusitis do not have major influence on scholastic performance of children as determined by this study which correlates with Mohamed Dirani et al ${ }^{18}$ But, Roberts JE et al ${ }^{19}$ in his study said that Children with otitis media with effusion and associated conductive hearing loss have been reported to score low in mathematics and expressive language.

\section{Conclusion}

In this study various interlinked factors such as socio economic status of parents, parents help in study, home environment, teachers influence, attendance problem, broken family had major impact on children's scholastic performance.

- Well educated parents shows positive influence on academic achievements of children by:

1) Helping them in studies

2) Providing physical and mental health.

3) Being a good role model for children.

- Teachers play a vital role in the academic performance of children. In this study $90 \%$ of children felt that teachers are encouraging, which showed positive influence on academic performance.

- Family disharmony like parental quarrel because of paternal alcoholism, broken homes showed negative influence on scholastic performance.

\section{Suggestions}

Valuable suggestions and advice can be made available by forming an association among parents, teachers, school management, educational authorities, health management.

1. Every effort should be made to find the cause in each child for his scholastic backwardness which should be managed through intensive individualized approach in a supportive environment.

2. Behavioral, emotional and psychological problems should be managed through behavior therapy and psychotherapy.

3. Family counseling and parental guidance are essential.

4. Teacher-student relationship should be strengthened.

5. A psychologist should be there in every educational institution to help students to maintain a sound mental health.

\section{References}

[1]. Sukumaran TU. Poor Scholastic Performance in Children and Adolescents. Indian Pediatrics. 2011;48:597-8.

[2]. Yuping Z. Influence of Home Environment on Children's Schooling: From Teacher's Perspective. Gansu Survey of Children and Families. 2011

[3]. American Academy of Pediatrics. Committee on Public Education. American Academy of Pediatrics : Children, Adolescents and Television . Pediatrics 2001:107:423-426

[4]. Lawrence AS, Vimala A. School Environment and Academic Achievement of Standard IX Students. Journal of Educational \& Instructional Studies in the World. 2012; 2(3): 210-5.

[5]. Coon H, Carey G, Fulker DW, Defries JC. Influences of School Environment on the Academic Achievement Scores of Adopted and Non -adopted Children. Intelligence. 1993; 17: 79-104

[6]. Screen KE. The Influence of Child-Parent and Child-Teacher relationships on the academic performance of children aged 10-12 Years. Children's Relationships and Academic Performance. 2011

[7]. Shah H. Psychosocial aspects of academic failure in children. Health Administer.17;34-7.

[8]. Yi-Lung K. The impact of psychosocial factors on achievement gains between eighth and tenth grade. University of Iowa. 2011.

[9]. Saraswati Shashidhar, Chandrika Rao and Radhakrishna Hegde. Factors Affecting Scholastic Performances of Adolescents. Indian Journal of Pediatrics 2009; 76 (5) : 495-499.

[10]. J N George, A A, S R. Scholastic Underachievement In Adolescents : A Comparative Study in Government And Private Schools and Jr. Colleges. Journal of Evolution of Medical and Dental Sciences. 2014;3(17):4548-4555

[11]. Meena Siwach nee Daulta Impact of Home Environment on the Scholastic Achievement of Children J. Hum. Ecol. (2008) : 23(1):75-77 
[12]. Shenoy J1, Kapur M. Prevalence of scholastic backwardness among children. Indian J Psychiatry. Oct 1996;38(4):201-7.

[13]. Bushra Iqbal Chohan, Impact of Parental Support on the Academic Performance and Self Concept of the Student .Journal of Research and reflections in Education 01/2010; 4:14-26.

[14]. Nair MK, Paul MK, Padmamohan J. Scholastic performance of adolescents. 2003. Indian J Pediatr; 70: 629-631

[15]. S. Paul Wright, Sandra P. Horn And William L. Sanders . Teacher And Classroom Context Effects On Student Achievement: Implications For Teacher Evaluation. Journal Of Personnel Evaluation In Education, 1997. 11: $57 \pm 67$

[16]. Amitava Raychaudhuri, Manojit Debnath, Saswata Sen and Braja Gopal Majumder. Factors Affecting Students' Academic Performance:A case study in Agartala Municipal Council Area. Bangladesh e-Journal of Sociology July 2010,. Volume 7, Number 2

[17]. Babalis, T. , Tsoli, K. , Nikolopoulos, V. \& Maniatis, P. . The Effect Of Divorce On School Performance And Behavior In School Children In Greece: An Empirical Study Of Teachers' Views. Psychology 2014, 5, 20-26.

[18]. McGrath CE, Watson AL, Chassin L. Academic achievement in adolescent children of alcoholics. J Stud Alcohol. Jan 1999; 60(1):18-26.

[19]. Roberts JE, Burchinal MR, Ziesel SA. Otitis Media in early childhood in relation to children's Academic Skills. Pediatrics 2002: $110: 696-706$

\section{Proforma}

1. Name :

2. Age : a) 10-13years $\quad$ b) 14-17years

3. Sex : a) Male b) Femal

ii) Fathers occupation: a) No Job b) Unskilled $\quad$ c) Skilled

d) Office going e) Professional \& Executive

4. i) Literacy status of mother: a) No schooling b) Primary school c) Secondary school
d) Higher secondary
e) Degree
f) Post graduate

g) Technical h) Professional

5. Type of family: a) Nuclear

b) Joint

c) Broken

6. Place of residence : a) Rural

b) Urban

7. Do you feel that your teacher is encouraging on your studies?:

8. a) Yes

b) No

9. Grade obtained in last examination:
a) $<35 \%$
b) $35-49 \%$
c) $50-59 \%$
d) $60-79 \%$
e) $>80 \%$

10. Does anyone at home help you at study? : a) Yes
If Yes, i) Father
ii) Mother

b) No

iv) Friends, Uncle, Aunt

11. Are there any factors like separate room, separate table, electric light, which facilitates studies at home? Yes b) No

12. Are there any factors which disturbs studies at home?
a) Yes
b) No

If Yes, i) Alcoholism/substance abuse

ii) Broken homeiii) Parental quarrels

13. Do you have any problem in attending school regularly? : a) Yes
If Yes, i) Personal illness
ii) Family problem
iii) Financial problem

b) No

14. Do you have any problems at school like partiality, harassment, isolation?:
a) Yes
b) No

15. Do you have eye problems like refractory errors, squint, stye?

a) Yes

b) No

16. Do you have any ENT problems like pain, discharge, hearing loss, and sinusitis?
: a) Yes
b) No

\section{CORRESPONDING AUTHOR}

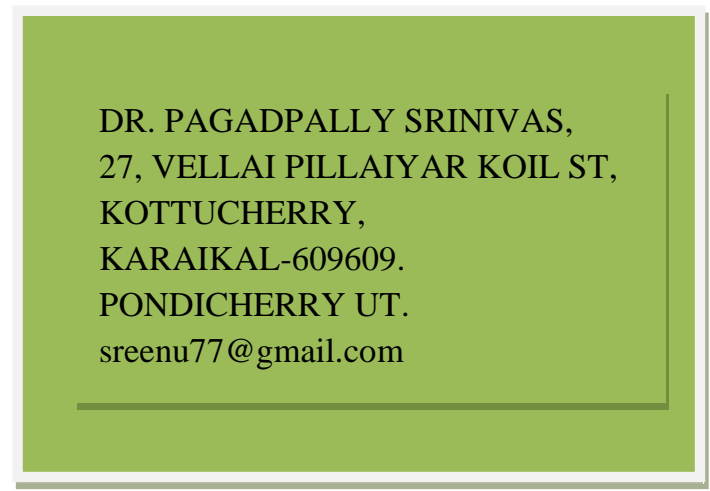

